\title{
MARINE BENTHIC ALGAE FROM THE \\ LEEWARD HAWAIIAN GROUP
}

\author{
By ROY T. TSUDA \\ BOTANY DEPARTMENT, UNIVERSITY OF HAWAII
}

Reprinted from

ATOLL RESEARCH BULLETIN NO. 115

THE PACIFIC SCIENCE BOARD

NATIONAL ACADEMY OF SCIENCES-NATIONAL RESEARCH COUNCIL

HONOLULU, HAWAII TECHNICAL REPORT NO.7 MARCH 1966




\section{No. 115}

Marine benthic algae from the leeward Hawaiian group

by

Roy T. Tsuda

Issued by

THE PACIFIC SCIENCE BOARD

National Academy of Sciences--National Research Council

Washington, D.C.

March 31, 1966 


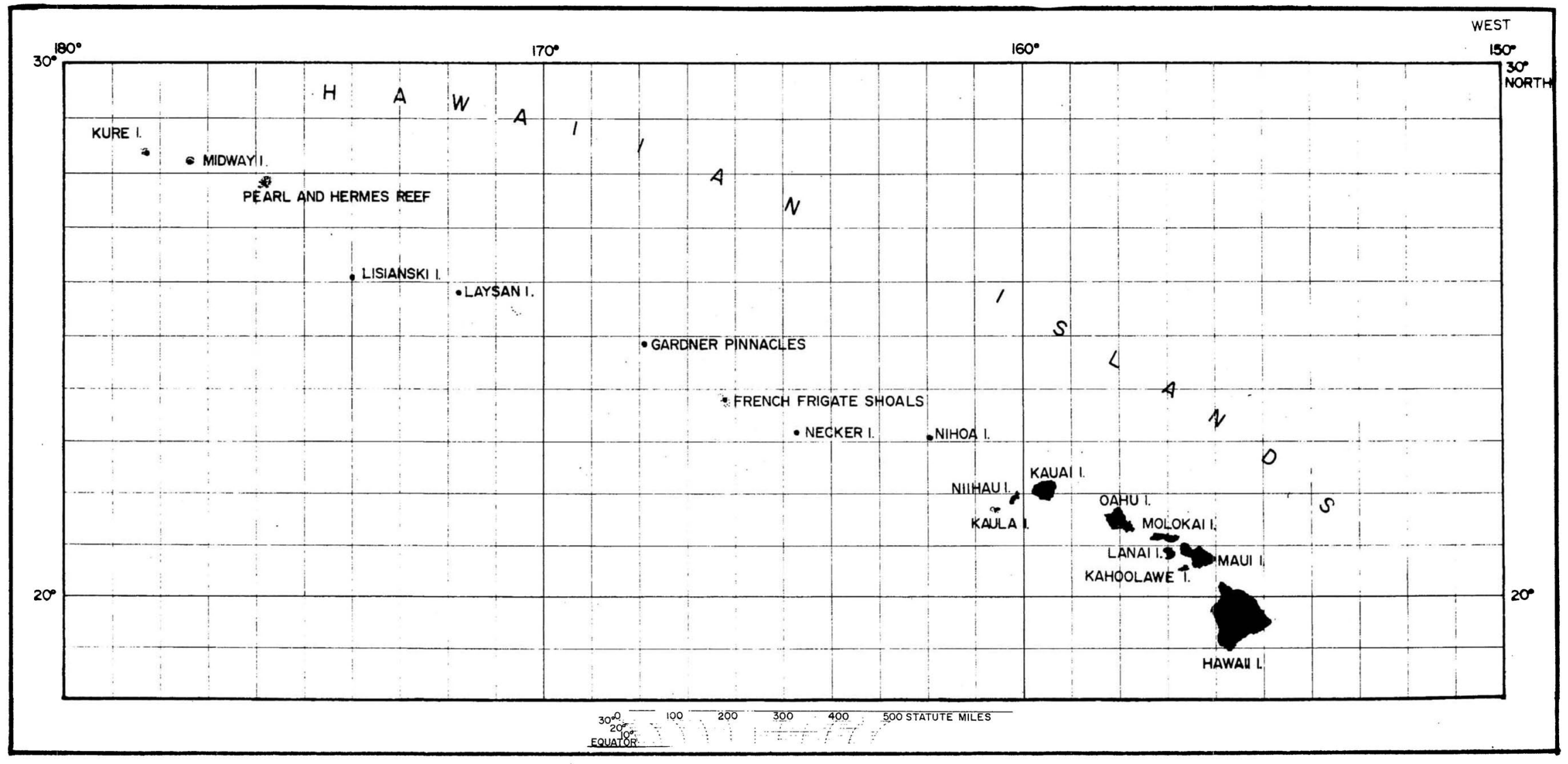

Fig. 1. Map of the Hawaiian Islands showing the relative position of each of the islands reported on. 


\title{
Marine Benthic Algae from the
}

\author{
Leeward Hawaiian Group]/ \\ by Roy T. Tsuda?/
}

The following is an account of all the marine benthic algae accumulated by the author from various collectors from six of the nine islands in the Ieeward Hawailan Group (Nihoa, Necker, French Frigate Shoals, Iisianski, Pearl and Hermes Reef, Kure). The islands comprising this group (Fig. I) consist of remnants of nine former high islands which at present make up low volcanic islands, reefs, and atolls. They extend approximately 1300 miles northwest from Kauai and are located between $23^{\circ} 05^{\prime} \mathrm{N}$. and $28^{\circ} 25^{\prime} \mathrm{N}$. Iatitude and $161^{\circ} 58^{\prime} \mathrm{W}$. and $17^{\circ} 25^{\prime} \mathrm{W}$. Iong1tude. For further information on the geography and history of each of these islands, see Bryan (1942).

Past published papers on the marine algae concern only three of the nine islands. These are Schauinsland (1899), Reinbold (1899), Lemmermann (1905), Tsuda (1965) on Laysan Island; Buggeln (1965) on Midway Island; and Howe (1934) on Pearl and Hermes Reef.

The fifteen species of algae reported in Howe (1934) on Pearl and Hermes Reef and one species of Turbinaria reported in Taylor (1964) from French Frigate Shoals are incorporated in this present paper. Except for them, all species listed represent new records. The recent algaI collections made from Laysan Island by Mr. C. R. Long in September 1964, are excluded since no new records were found. Any name which is now relegated to synonymy is cited with the currently accepted name.

Also included in this paper are the corrected specific epithets of three species of Liagora and one species of Halimeda which were reported inaccurately fron Iaysan Island (Tsuda, 1965) and MIdway Island (Buggeln, 1965).

Below is a list of the islands with the collectors, dates and specimen numbers as available. The initials within the parentheses identify the specimen numbers of Dr. Maxwell S. Doty, Dr. Charles H. Lamoureux, Mr. Ronald Walker, and the author.

NIHOA ISTAND ( $23^{\circ} 05^{\prime} \mathrm{N}$. Lat., $161^{\circ} 58^{\prime} \mathrm{W}$. Long.):

E. Christophersen, July 1924; R. Walker, March 1964 (RW 2).

NECKER ISLAND (230 10' N. Lat., $164041^{\prime}$ W. Iong.):

E. Christophersen, July 1924; C. R. Iong, September 1964 (RT 938-955).

1)

Technical Report INo. 7, Hawail Marine Laboratory, University of Hawail. 2/

Department of Botany, University of Hawail, Honolulu, Hawaii 96822. 
FRENCH FRICATE SHOALS ( $23^{\circ} 50^{\prime} \mathrm{N}$. Lat., $166^{\circ} 15^{\prime}$ W. Long.): C. T. Crocker, December 1936 (in Taylor, 1964); R. Rogers, March 1961 (MSD 19476); C. R. Long, September 1964 (RT 931-937).

LISIANSKI ISLAND (260 $02^{\prime}$ N. Lat., $173^{\circ} 59^{\prime}$ W. Long.): S. C. Ball (Tanager Expedition), April 1923; A. L. Young, August 1964 (RT 637-645); C. R. Long, September 1964 (RT 920-928).

PEARL AND HERMES REEF (270 $50^{\prime}$ No Lat., $175^{\circ} 50^{\prime}$ W. Long.): P. C. Galtsoff, Summer 1930 (in Howe, 1934); E. C. Jones, June 1956 (MSD 13346); A. L. Young, August 1964 (RT 613-633); C. R. Long, September 1964 (RT 899-919).

KURE ATOLI ( $28^{\circ} 25^{\prime}$ N. Lat., $178^{\circ} 25^{\prime}$ W. Long.): C. H. Lamoureux, September 1961 (MSD 19573-19576, CHL 2778); A. Anderson, Merrch 1965 (RT 980-986).

In the following annotated list, the specimen numbers are listed with the species and by their use the collectors can be determined.

\section{MYXOPHYTA} Drouet.

Species determinations in this group are contributed by Dr. Francis Lyngbya aestuarii (Mert.) Lyngb.

French Frigate Shoals: RT 937 (E'ast Island - on reef flat).

Iyngbya majuscula (Dillw.) Harv.

Pearl and Hermes Reef: RT 914 (North Island - on reef flat), RT 916 (in central lagoon); Kure Atoll: MSD 19576A (Green Island - on reef flat).

Oscillatoria chalybea Mert.

Necker Island: RT 938 (west point of island).

Schizothrix mascarenica Gom.

Kure Atoll: CHL 2778 (Green Island - forming crust in sand about $5 \mathrm{~mm}$ thicks on edge of dune facing lagoon beach). 
Cladophora sp.

Pearl and Hermes Reef: RT 627 (Bird Island - entangled mass of yellowish-green filaments with spongy texture).

Codium arabicum KHtzing, 1856: 35, pl. 100 (fig. II).

(Codium coronatum Setchell)

Pearl and Hermes Reef: Howe (in 3 meters of water). Egerod (1952) relegates $\underline{\mathrm{C}}$. coronatum to synonymy under $\underline{\mathrm{C}}$. arabicum.

Codium edule Silva in Egerod, 1952: 392, figs. 18a-c, pl. 35.

French Frigate Shoals: RT 932 (Trig Island); Lisianski Island: RT 927 (on eastern beach).

Dictyosphaeria cavernosa (Forsskll) Boerg., 1932: 2, pl. I (fig. 1); Egerod, 1952: 350, fig. le-g.

Kure Atoll: RT 982 (Green Island - beachdrift).

Distyosphaeria versluysii Weber-van Bosse, 1905: 144; Egerod, 1952: 35I, figs. Ia and $2 \mathrm{~h}-\mathrm{k}$.

Lisianski Island: RT 642; Pearl and Hermes Reef: RT 903 (Southeast Island - beachdrift).

Enteromorpha tubulosa Ktttzing, 1856: 11; Dewson, 1954: 384, figs.6a-b.

Pearl and Hermes Reef: RT $9 I 1$ (Southeast Island - on rocks on west side of island).

Enteromorpha sp. I

Iisianski Island: RT 645 (on coral); Pearl and Hermes Reef: RT 628 (North Island - on coral).

Enteromorpha sp. 2

Kure Atol1: MSD 19576D (Green Island - small thallus branching profusely from base).

Enteromorpha sp. 3

Pearl and Hermes Reef: RT 913 (Southeast Island - in shallow pool). 


\section{CHIOROPHYTA}

Bryopsis pennata Lamx., 1809a: 134, figs. la-b, pl. 3; Egerod, 1952: 370 , fig. 7 .

Necker Island: RT 950; Lislanski Island: RT 736 (on reef flat).

Caulerpa racemosa var. clavifera (Turner) Weber-van Bosse, 1898: 361, pl. 33 (figs. $1=5$ ).

Necker Island: Christophersen (det. by Dr. W. J. Gilbert).

Caulerpa racemosa var. imbricata (Kjellm.) Eubank, 1946: 423, fig. 2w. Necker Island: RT 944.

Caulerpa racemosa var. laetevirens (Mont.) Weber-van Bosse, 1898: 366, p1. 33 (figs. 8, 16-22).

Necker Island: Christophersen (det. by Dr. W. J. Gilbert).

Caulerpa racemosa var. peltata (Lamx.) Eubank, 1946: 421, figs. 2r-s. Necker Island: RT 943.

Caulerpa serrulata (Forssk.) J. Ag. emend Boergesen, 1932: 5, pl. I (fig. 2).

Pearl and Hermes Reef: Howe (in a meter of water).

Caulerpa taxifolia (Vahl) C. Ag., 1822: 435; Eubank, 1946: 417, figs. $2 f-g$.

Nihoa Island: Christophersen (det. by Dr. W. J. Gilbert).

Chaetomorpha antennina (Bory) Kutzing, 1849: 379; Boergesen, 1940: 38. Necker Island: RT 953.

Chlorodesmis hildebrandti1 A. \& E. S. Gepp, 1911: 16, 137, figs. 74-75; Egerod, 1952: 377, fig. 9b, pl. $34 a$.

Lisianski Island: RT 644 (small filaments about $2-3 \mathrm{~mm}$ in length attached to coral). 
Halimeda discoidea Decaisne, 1842: 91; Hillis, 1959: 352, pl. 2 (fig. 5), pI. 5 (fig. 1I), pl. 6 (fig. 11), pl. 7 (figs.9-10), p1. 8 (figs. 5-8), pl. 11 .

Lisianski Island: RT 638, RT 922 (on eastern beach); Pearl and Hermes Reef: Howe, as H. cuneata Hering (in a meter of water). Hillis in her monograph of the genus Halimeda lists the specimen identified by Howe as $\underline{H}$. cuneata Hering under $\underline{H}$. discoidea Decaisne.

Halimeda opuntia (L.) Lamx., 1816: 308; Hillis, 1959: 359, pl. 2 (figs. $7-8$ ), pl. 5 (figs. 3-4), pl. 6 (fig. 6), pl. 7 (fig. 3), pl. 10 .

Pearl and Hermes Reef: Howe (small segmented form in about 7 meters of water); Midway Island: MSD 18707, MSD 18738, MSD 18747, MSD 18758 (as H. incrassata (Ellis) Lamx. in Buggeln, 1965); Laysan Island: Tanagēr Expedition (as $\mathrm{H}$. lacunal is Taylor in Tsuda, 1965).

The author in an earlier (1965) paper had listed $\mathrm{H}$. lacunalis Taylor as occurring on Laysan while Mr. Richard Buggeln listed H. incrassata (EIIis) Lamx. as occurring on Midway (BuggeIn, 1965). After a more thorough study of these two specimens, Mr. Buggein and the author agree that both are juvenile forms of $H$. opuntia, with this decision later verified by $\mathrm{Dr}$. William J. Gilbert.

These two specimens each have a single distinct holdfast, while anatomically the central filaments at the internode are fused in pairs and the utricles fall within the size range as specified in Hillis(1959).

Microdictyon setchellianum Howe, 1934: 38; Egerod, 1952: 366, figs. 6c-g, pl. 33 .

Necker Island: RT 954; French Frigate Shoals: RT 933 (Trig Island); Pearl and Hermes Reef: Howe (in about 7 meters of water), RT 618 (Bird Island - epiphytic on Laurencia obtusa (Huds.) Iamx.), RT 624 (Bird Island), RT 902 (Southeast Island-beachdrift); Kure Atoll: RT 986 (Green Island - beachdrift).

Ulva fasciata Delile, 1813: 153; Boergesen, 1940: 10. Necker Island: RT 942.

\section{PHAEOPHYTA}

Colpomenia sinuosa (Roth) Derbes \& Solier, 1856: 11; Dawson, 1954: 402, figs. 18a, c, d.

Pearl and Hermes Reef: Howe (epiphytic on Halimeda opuntia (I.) Lamx. In about 7 meters of water). 
Chnoospora minima (Hering) Papenfuss, 1956: 69.

Necker Island: RT 947.

Dictyota friabilis Setchell, 1926: 91, pl. 13 (figs. 4-7) and pl. 20 (fig. I).

Necker Island: RT 948 (fragments); Pearl and Hermes Reef: RT 617 (Bird Island - epiphytic on Laurencia obtusa (Huds.) Lamx.)

Dictyota $\mathrm{sp}$.

Kure Atoll: RT 981 (Green Island - beachdrift).

Hydroclathrus clathratus (C. Ag.) Howe, 1920: 590.

Pearl and Hermes Reef: Howe (in about a meter of water).

Pocockiella variegata (Lamx.) Papenfuss, 1943: 467, figs. 1-14.

Lisianski Island: RT 640 (small prostrate thallus adhering to coral); Kure Atol1: RT 985 (Green Island - beachdrift).

Sargassum echinocarpum J. Ag., 1848: 327.

Nihoa Island: EW 2: Necker Island: RT 941.

Sargassum obtusifolium J. Ag., 1848: 339.

(Sargassum vulgare var. IinearifoliumJ. Ag.)

Pearl and Hermes Reef: Howe (in about 7 meters of water on coral and sand, probabiy unattacied).

Howe (1934) places a question mark after this variety, but says that this specimen agrees very well with Yendo (1907). At present, Doty \& Newhouse (unpublished manuscript) places this variety under the

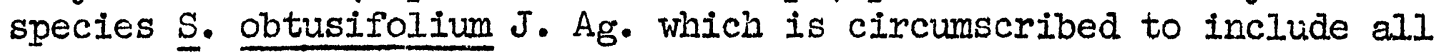
round and smooth stermed Sargassums from Hawaii.

Sargassum piluliferum (Turn.) C. Ag., 1821: 27.

Pearl and Hermes Reef: Howe (floating in 2 meters of water),

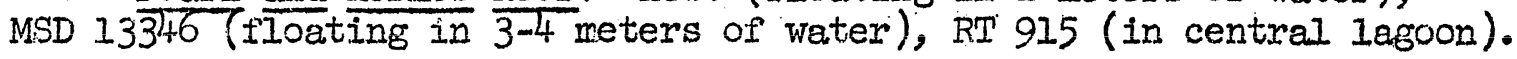

Specimen RT 915 is very light brown in color, with proilferations on the main axis, narrow leaf-segments, and numerous air vesicles on short pedicels. 
Sphacelaria tribuloides Meneghini, 1840: 2; Boergesen, 1941: 41, figs. $18 a-c$.

Pearl and Hermes Reef: RT 633A (Bird Island - on coral).

Turbinaria ornata (Turner) J. Ag., 1848: 266; Taylor, 1964: 483.

French Frigate Shoals: (reported in Taylor, 1964); Lisianski Island: RT 921 (on eastern side of island); Pearl and Hermes Reef: Howe (in about a meter of water), RT 620 (Bird IsIand), RT 899 (Southeast Island - beachdrift); Kure Atoll: MSD 19573 (Green Island - beachdrift).

Zonaria sp.

Pearl and Hermes Reef: RT 613 (Bird Island); Kure Atoll: MSD 19575 and RT 980 (Green Island - beachdrift).

RHODOPHYTA

Acrochaetium sp.

Pearl and Hermes Reef: RT 622 (Bird Island - epiphytic on Turbinaria ormata (Turner) J. Ag.).

Amphiroa fragillisima (L.) Lamx., 1816: 298; Taylor, 1960: 403,pl. 47 (fiçs. 1-2).

Lisianski Island: RT 641, RT 926 (on eastern beach).

Bangia fuscopurpurea (Dillwyn) Lyngbye, 1819: 83; Taylor, 1960: 293. French Frigate Shoa].S: MSD 19476 (as a tuft near high tide line on La Perouse Rock). Det. by Dr. Maxwell S. Doty.

Centroceras apiculatum Yamada, 1944a: 42.

Pearl and Hermes Reef: RT 629 (Bird Island - on piece of coral), RT 908 (SUitionet Island - beachdrift, epiphytic on Microäictyon setcbellianum Howe).

Centroceras clerrulatum (C. Ag.) Montagne in Durieu, 1846: 140; Dawson, 1954: $446, \mathrm{tig}$. $54 \mathrm{~h}$.

Necker Island; RT 955; Kure Atoll: MSD 19576E (Green Island). 
Ceramium gracillimum Griffiths \& Harvey in Harvey, 1846-1851, pl. 206. French Frigate Shoals: RT 936 (East Island).

Ceramium mazatlanense Dawson, 1950b: 130, pl. 2 (figs. 14-15).

(I. ) Lamx.).

Iisianski Island: RT 643 (epiphytic on Amphiroa Pragillisima

Falkenbergia hillebrandii (Bornet) Falkenbert = sporophyte generation of Asparagopsis taxiformis (Delile) Collins \& Hervey; Feldmann \& Feldmann, 1942: 89; Dawson, 1954: 414, fig. 25I.

Pearl and Hermes Reef: RT 623 (Bird Island).

Gelidium pusillum (Stackh.) Le Jolis, 1864: 139; Dawson, 1954: 420, figs. 3la-c.

Necker Island: RT 952; Lisianski Island: Ball (tuft on coral), RT 920 (on east beach); Pearl and Hermes Reef: RT 626 (Bird Island juvenile forms covering small piece of coral).

Goniolithon frutescens Fosl., 1900: 9.

Pearl and Hermes Reef: Howe (in a meter of water).

Griffithsia ovalis Harvey, 1862, vol. 4: pl. 203; Abbott, 1946: 440, pl. 1 (figs. 1-4); pl. 2 (figs. 1-2).

Pearl and Fermes Reef: RT 910 (Southeast Island - beachdrift, epiphytic on Microdictyon setchellianum Howe). This sterile bead-Iike thallus about a centimeter long is tentatively listed under this species.

Haloplegma sp.

Kure Atoll: RT 984 (Green Island - beachdrift).

Herposiphonia sp. 1

French Frigate Shoals: RT 934A (Trig Island). At present, Dr. G. J. Hollenberg is studying all of these specimens of Herposiphonie from the leeward group and will report on them later. 
Herposiphonia sp. 2

Pearl and Hermes Reef: RT 625 (Bird Island - epiphytic on Microdictyon setchellianum Howe).

Herposiphonia sp. 3

Pearl and Hermes Reef: RT 906 (Southeast Island - beachdrift, epiphytic on Microdictyon setchellianum Howe), RT 912 (on rocks on west side of island).

Hypnea pannosa J. Ag., 1847: 14; Tanaka, 1941: 247, fig. 20.

Necker Island: RT 945 (forming entangled clumps).

Hypnea sp.

Lisianski Island: RT 925 (epiphytic on base of Halimeda discoidea Decaisne on eastern beach); Pearl and Hermes Reef: RT 919 (central lagoon - epiphytic on Sargassum piluliferum (Turn.) C. Ag.).

Jania capillacea Harvey, 1853: 84; Dawson, 1952: 116.

Necker Island: RT 951 (epiphytic on Sargassum echinocarpum J. Ag.); Iisianski Island: RT 923 (epiphytic on Turbinaria ornata (Turner) J. Ag. on eastern beach); Pearl and Hermes Reef: RT 907 (Southeast Island beachdrift, epiphytic on Microdictyon setchellianum Howe); Kure Atoll: MSD 19576 (Green Island - epiphytic on Turbinaria ornata (Turner) J. Ag.).

Jania ungulata Yendo, 1902: 27, pl. 3 (figs. 7-8) and pl. 7 (fig. 8).

Pearl and Hermes Reef: RT 621 (Bird Island - epiphytic on Turbinaria ornata (Turner) J. Ag. ).

Iaurencia galtsoffi Howe, 1934: 39.

Pearl and Hermes Reef: Howe (on sand and coral in 3 meters of water).

Laurencia obtusa (Huds.) Lamx., 1813: 130; Yamada, 1931: 222, p1. 16 (figs. a-e) and pl. 17 (figs. a-c).

Necker Isiand: RT 940; French Frigate Shoals: RT 931 (Trig IsIand); Pearl and Hermes Reef: RT 616 (Bird Island), RT 904 (Southeast Island - beachdrift), RT 917 (in central lagcon); Fure Atoll: RT 983

(Green Island - beachdrift). 
Laurencia sp. 1

Pearl and Hermes Reef: Howe (on coral sand in 7 meters of water).

Laurencia sp. 2

French Frigate Shoals: RT 935 (Trig Island).

Laurencia sp. 3

Kure Atoll: MSD 19576B (Green Island).

Liagora ceranoides Lainx. f. pulverulenta (C. Ag.) Yamada, 1938: 20; Abott, 1945: 156, figs. 8-9.

Pearl and Hermes Reef: RT 900 (Southeast Island - beachdrift). Male thallus about $11 \mathrm{~cm}$ in height, determined by Dr. I. A.Abbott.

Liagora farinosa Lamx., 1816: 240; Abbott, 1945: 163, figs. 14-15.

Laysan: MSD 19584 (determined as I. kahukuanaAbbott in Tsuda, 1965). This specimen was sent to Dr. I. A. Abbott for verification and according to her, it is not $I$. kahukuana Abbott but falls within the circumscription of I. farinosa Lamx.

Liagora kahukuana Abbott, 1945: 149, fig. 2.

Laysan: Tanager Expedition (as Liagora sp. 2 in Tsuda, 1965). Determined by Dr. I. A. Abbott.

Liagora valida Harvey, 1852: 138, pl. 3la (figs. 1-5); Abbott, 1945: 160, figs. 12-13.

Laysan: Tanager Expedition (as Liagora sp. I in Tsuda, 1965). Determined by Dr. I. A. Abbott.

\section{I. iagora $\mathrm{sp}$.}

Pearl and Hermes Reef: RT 901 (Southeast Island - beachdrift). Upon examination of this male specimen, Dr. I. A. Abbott reports that it is verry close to ${ }_{\text {. }}$ valida Harvey in internal structure but differs externaily.

Iitihophyi]urn sp.

Pearl and Hermes Reef: Howe (on broken corals in 1-2 meters of water). 
Polysiphonia simplex Hollenberg, 1942: 782, fig. 18.

French Frigate Shoals: RT 934B (Trig Island). Species determination by Dr. G. J. Hollenberg.

Polysiphonia villum J. Ag., 1863: 941.

Pearl and Hermes Reef: RT 633B (Bird Island - on piece of coral). Det. by Dr. G. J. Hollenberg.

Ponolithon sp. water).

Pearl and Hermes Reef: Howe (on broken coral in 1-2 meters of

Spyridia filamentosa (Wulf.) Harv. in Hooker, 1833: 337; Dawson, 1954: 444, fig. $54 i$.

Lislanski Island: RT 928 (on east beach); Pearl and Hermes Reef: RT 615 (Bird Is Iand - epiphytic on Zonaria sp.).

\section{Acknowledgments}

The majority of the specimens reported here were collected under the auspices of the Pacific Ocean Biological Survey Program, Division of Birds, Smithsonian Institution, by Dr. Charles H. Lamoureux, Mr. C.R. Long, Mr. Alan I. Young, and Mr. Alan Anderson. The specimens are in the possession of the Department of Botany, University of Hawail, with a second set being sent to the Smithsonian Institution.

The author is grateful to Dr. Isabella A. Abbott, Hopkins Marine Station, for her determinations of Liagora; to Dr. Francis Drouet, Academy of Natural Sciences of Philadelphia, for providing the determinations of all the blue-green algae; to Dr. William J. Gilbert, Albion College, for his verification of $\mathrm{H}$. opuntia; and to Dr. George J. Hollenberg, Professor Emeritus of Biology, University of Redlands, for the species determinations of Polysiphonia. 
Summary of Algal Collections

Table I summarizes the number of marine benthic algal species or varieties in each of the major divisions thus far recorded from each of the eight islands in the Leeward Hawaiian group. To date, no algal collections have been made from Gardner Pinnacles. By observing this table one can see the discrepancy between the number of algae from Laysan Island as compared to the number of algae from the other islands. More work on algal floristics is needed on these other islands, since Laysan is the only island on which a thorough collection has been made.

Table I. Number of marine benthic algae from the Leeward Hawaiian Group

\begin{tabular}{|c|c|c|c|c|c|}
\hline Islands & Myxophyta & Chlorophyta & Phaeophyta & Rhodophyta & Total \\
\hline Nihoa Island & 0 & 1 & 1 & 0 & 2 \\
\hline Necker Island & 1 & 8 & 3 & 5 & 17 \\
\hline $\begin{array}{l}\text { French Frigate } \\
\text { Shoals }\end{array}$ & 1 & 2 & 1 & 6 & 10 \\
\hline $\begin{array}{l}\text { Iisianski } \\
\text { Island }\end{array}$ & 0 & 6 & 2 & 6 & 14 \\
\hline $\begin{array}{l}\text { Pearl \& Hermes } \\
\text { Reef }\end{array}$ & 1 & 10 & 8 & 20 & 39 \\
\hline Kure AtolI & 2 & 3 & 4 & 5 & .14 \\
\hline $\begin{array}{l}\text { Midway } \\
\text { Islands } \\
\text { (Buggeln, } \\
\text { 1965) }\end{array}$ & 1 & 11 & 5 & 17 & 34 \\
\hline $\begin{array}{l}\text { Laysan } \\
\text { Island. } \\
\text { (1suda, } \\
1965 \text { ) }\end{array}$ & 17 & 23 & 17 & 46 & 103 \\
\hline
\end{tabular}


Selected Bibliography

Abbott, I. A. 1945. The genus Liagora (Rhodophyceae) in Hawaii. Occ. Pap. B. P. Bis. Mus. XVIII(10): 145-169, figs. 1-16.

Bryan, E. H., Jr. 1942. American Polynesia and the Hawalian Chain. Tongg Publ. Co., Honolulu. $253 \mathrm{pp}$.

Buggeln, R. G. 1965. A preliminary list of the algal flora of the Midway Islands. Atoll Res. Bull. 109: I-Il.

Egerod, L. 1952. An analysis of the siphonous Chlorophycophyta. Calif. Univ., Publ., Bot. 25: 325-454, figs. 1-23, pls. 29-42.

Eubank, L. 1946. Hawaiian representatives of the genus Caulerpa. Calif. Univ., Publ., Bot. 18: 409-432, figs. 1-2.

Hillis, L. W. 1959. A revision of the genus Halimeda. Inst. Mar. Sci. VI: 321-403, pl. 1-12.

Howe, M. A. 1934. Hawaiian algae collected by Dr. Paul C. Galtsoff. Journ. Wash. Acad. Sci. 24(1): 32-42.

Lemmermann, E. 1905. Die Algenflora der Sandwich-Inseln. Bot. Jahrb. 35: 607-663.

Reinbold, T. 1899. Meersalgen. Ergebnisse einer Reise nach dem Pacific, H. Schauinsland 1896-1897. Abhandl. Naturw. Verein, Bremen. 287-302.

Schauinsland, H. 1899. Drei Monate auf einer Korallen-InseIn. (Laysan). Abhandl. Naturw. Verein, Bremen. I-104.

Taylor, W. R. 1964. The genus Turbinaria in eastern seas. Journ. Linn. Soc. (Bot.) 58(374): $475-487$.

Tsuda, R. T. 1965. Marine algae from Laysan Island with additional notes on the vascular flora. Atoll Res. Bull. 110: 1-31. 